Slaveholding and Jesuit Recordkeeping in the Maryland Province of the Society of Jesus, 1717-1867

Author: Elsa B. Mendoza

Source: Engaging Sources: The Tradition and Future of Collecting History in the Society of Jesus (Proceedings of the Symposium held at Boston College, June 11-13, 2019)

Edited by: Cristiano Casalini, Emanuele Colombo, and Seth Meehan

ISBN: 978-1-947617-09-4

Published by: Institute of Jesuit Sources

Originally Published: March 1, 2021

https://doi.org/10.51238/ISJS.2019.11

Provided in Open Access by the Institute for Advanced Jesuit Studies at Boston College.

The Institute of Jesuit Sources, specializes in preserving, maintaining, and expanding for scholars around the world important texts and studies in Jesuit history, spirituality, and pedagogy.

Visit our website at https://jesuitsources.bc.edu 


\title{
Slaveholding and Jesuit Recordkeeping in the Maryland Province of the Society of Jesus, 1717-1867
}

\author{
ELSA B. MENDOZA
}

On November 5, 1755, Nanny, a woman enslaved by the Maryland Jesuits, gave birth to a boy named John at Bohemia plantation. The records show that the superior at Bohemia, Fr. John Lewis, christened John six days after his birth. His godparents, Isaac and Betty, were part of the plantation's enslaved community. However, Lewis did not register John's birth in the sacramental books of Francis Xavier, the plantation parish. Instead, he registered the birth and christening on his daybook, along with crop numbers, the names of enslaved laborers during the harvest, and the amount of corn produced in neighboring Jesuit plantations. John's birth and the birth of at least ten enslaved children in eighteenth-century Bohemia only exist in the Jesuit financial records, scattered between entries for traveling costs between plantations and prices of grain and eggs. ${ }^{1}$

This paper analyzes how the Maryland Jesuits kept records of the people they enslaved. By examining financial ledgers, sacramental books, and correspondence from the Maryland Province Archives, it will present a chronological survey of Jesuit recordkeeping. In doing so, it will offer two interconnected arguments. First, that the Jesuits' documenting practices were contingent on their need to preserve their property holdings and three external forces: state regulations, the needs of the early American church, and Rome's supervision. Second, that Jesuit bookkeeping reveals that the Maryland Jesuits saw the persons they enslaved and catechized primarily as property, not members of their congregation, or part of the body of Christ as some of the mission's superiors maintained. ${ }^{2}$

Since the early years of the mission, the Maryland Jesuits were haphazard record-keepers. To the dismay of Rome, they did not comply with Juan Alfonso de

\footnotetext{
1 "Bohemia Accounts, 1735-1561" [Oversize Box 1], Maryland Province Archives of the Society of Jesus (hereafter MPA), Booth Family Center for Special Collections, Lauinger Library, Georgetown University. For the sacramental records of Francis Xavier church during the period, see Joseph C. Cann, History of Saint Francis Xavier Church and Bohemia Plantation, Now Known as Old Bohemia, Warwick Maryland (n.p.: The Society, 1976).

${ }^{2}$ On the Jesuits' insistence that they saw enslaved persons as part of the body of Christ and as an integral part of their mission, see Rev. George Hunter's reflections, Box 57, Folder 1, MPA; on enslaved persons as "Brothers in Christ," see John Lewis, "Traditus est propter delicta nostra. St. ad Rom. 4C. 25V: Who Was Delivered Up for Our Sins," American Catholic Sermons' Collection (hereafter cited as ACSC), Box 4, Folder 47. On broader Jesuit theology on the relationship between the enslaved and the body of Christ, see Alonso de Sandoval, Un tratado sobre la esclavitud, ed. Enriqueta Vila Vilar (Madrid: Alianza Editorial, 1987), 256-60.
} 
Polanco's recordkeeping principles. ${ }^{3}$ They kept lacunose and inconsistent records in every part of their missionary life. Some priests wrote detailed lists of baptisms, christenings, and marriages, while others jotted down sacraments next to their wine purchases. ${ }^{4}$ These disjointed practices were also common in their accounts, including those related to their most valuable asset, their human property. ${ }^{5} \mathrm{Few}$ plantation managers kept detailed accounts of their estate's income or the persons enslaved at their plantations. Others took years to record a single transaction in their ledgers, including sales of persons. ${ }^{6}$ This chaotic system led fellow Jesuits to deem some financial ledgers as unreliable, doubting the veracity of recorded transactions. ${ }^{7}$

The bookkeeping of the Maryland mission is incompatible with historians' descriptions of Jesuit accounting practices. ${ }^{8}$ To illustrate, in the pre-suppression

${ }^{3}$ On Jesuit recordkeeping and Polanco, see Paul Nelles, "Jesuit Letters," in The Oxford Handbook of the Jesuits, ed. Ines G. Županov (New York: Oxford University Press, 2019), 44-72; Paul Nelles, "Chancillería en colegio: La producción y circulación de papeles jesuitas en el siglo XVI," Cuadernos de historia moderna: Añejos 13 (2014): 49-70; Richard H. Dowling, S.J., "Juan de Polanco, S.J., 1517-1576," Woodstock Letters 69, no. 1 (February 1940): 1-20; José García de Castro, Polanco: El humanismo de los jesuitas (1517-1576) (Bilbao: Universidad Pontificia Comillas, 2012); Juan Alfonso de Polanco, "Reglas que deven observer acerca de escribir los de la Companía que están esparcidos fuera de Roma," in Monumenta Ignatiana: Epistolae et instrucciones (Madrid: López del Horno, 1903), 1:542-49.

${ }^{4}$ For an example of a detailed sacramental register of the mission during the eighteenth century, see "Marriage Register of Joseph Mosley, S.J., and John Bolton," Box 4, Folder 4, MPA. For birth records in financial transactions, see "Bohemia Accounts, 1735-1561" [Oversize Box 1], MPA.

${ }^{5}$ On the Maryland Jesuits' wealth, see Robert Emmett Curran, “'Splendid Poverty': Jesuit Slaveholding in Maryland, 1805-1838," in Catholics in the Old South: Essays on Church and Culture, ed. Jon L. Wakelyn and Randall M. Miller (Macon, GA: Mercer University Press, 1999), 125-46; Thomas Murphy, S.J., "Real Poverty and Apparent Wealth on the Jesuit Farms," in Jesuit Slaveholding in Maryland, 1717-1838 (New York: Routledge, 2001), 33-62; "The Maryland Missions in 1765," Box 57, Folder 1, MPA; "The White Marsh Memorandum, 1764," in History of the Society of Jesus in North America, Colonial and Federal Documents, Vol. 1: Part 1; Nos. 1-141 (16051838), ed. Thomas Hughes (Cleveland: Burrows Brothers Company, 1908), 230-31.

${ }^{6}$ Bohemia plantation provides examples of different types of recordkeeping. Its ledger from 1790 to 1870 has detailed accounts in the first years and a fifty-year gap between 1799 and 1849 . See "Bohemia Ledger, 1790-1870," Box 49, Folder 3, MPA.

${ }^{7}$ McElroy expressed doubts about the accounting of his fellow Jesuits during his time as agent, see "Agents Cashbook 1802-1820 by Fr. McElroy," Box 69, Addenda to the Maryland Province Archives (hereafter Addenda), Booth Family Center for Special Collections, Georgetown University. During the twentieth century, the procurator of the Maryland province, Fr. Joseph Zwinge, also expressed doubts about the veracity of nineteenth-century bookkeeping in the province, see "Zwinge's Notes on Bohemia Land Patents," Box 30, Folder 7, MPA; "Annotation: Backmatter," "Bohemia Ledger, 1790-1870," Box 49, Folder 3, MPA; "St. Inigoes Account Book, 1816-1832," Box 44, Folder 1, MPA.

${ }^{8}$ The historiography of Jesuit missions, particularly in Latin America, has emphasized this positive assessment of Jesuits as efficient managers of estates. However, the Maryland Jesuits stand in contrast with their counterparts in the southern part of the continent. See François Chevalier, La formación de los latifundios en México: Haciendas y Sociedad en los siglos XVI, XVII y XVIII (México: Fondo de Cultura Económica, 1976); James Denson Riley, Hacendados jesuitas en México: La administración de los bienes inmuebles del Colegio Máximo de San Pedro y San Pablo, 1685-1767 (México: Secretaria de Educación Pública, 1976), 169-70, 173-75; Herman W. Konrad, A Jesuit Hacienda in Colonial Mexico, Santa Lucía, 1576, 1767 (Stanford: Stanford University 
period Jesuits in New Spain extensively documented their activities, and Jesuit brothers used operation manuals that regulated every aspect of an estate's administration. They wrote detailed inventories of the persons held in bondage at estates such as Santa Lucía owned by the Jesuit College of San Pedro y San Pablo in central Mexico. ${ }^{9}$ Meanwhile, the members of the Maryland mission recorded the names of the persons they held in bondage infrequently and had no brothers to assist in their plantations. ${ }^{10}$ These accounting incongruities did not change after the order's restoration: in 1820, a visitor from Rome was confronted with chaotic records in Maryland, where some estates had not kept financial records for decades. ${ }^{11}$

These discrepancies in archival practices emphasize the importance of studying bookkeeping to understand the Maryland mission, as they might reveal why, by the mid-nineteenth century, this province was known as "the diseased limb of the Society."12 Recordkeeping practices reveal intentions, goals, and internal workings of organizations. Archival production illuminates the past of individuals and

Press, 1980); Nicholas P. Cushner, Lords of the Land: Sugar, Wine, and Jesuit Estates of Coastal Peru, 1600-1767 (Albany: State University of New York Press, 1980).

${ }^{9}$ These instructions were published by François Chevalier, see Instrucciones a los hermanos jesuitas administradores de haciendas (México: UNAM Instituto de Historia, 1950). Other estates in New Spain had detailed instructions for their administration. See Jean Pierre Berthe, Xochimancas: Los trabajadores y los días en una Hacienda Azucarera de Nueva España en el siglo XVIII (Tunja, Colombia: Ediciones Pato Marino, 1975). For other instructions in South America, see Pablo Macera, Instrucciones para el manejo de las haciendas Jesuitas del Perú, ss. XVII-XVIII, Nueva Crónica 2 (Lima: Universidad Nacional Mayor de San Marcos, Facultad de Letras y Ciencias Humanas, Departamento de Historia, 1966). For Santa Lucía's enslaved community, see Konrad, Jesuit Hacienda in Colonial Mexico, 246-66; Riley, Hacendados Jesuitas en México, 168-80.

${ }^{10}$ From 1758 to 1809 , the Maryland mission did not count Jesuit brothers. See Catalog of Members of the Maryland Mission of the Society of Jesus, 1634-1806, n.p.: n.p., n.d. For the years 1807-10, see Catalogus Sociorum Missionis Federatae Societatis Jesu, 1807 (Woodstock: Ex Typis Collegii Ss. Cordis, 1887); Catalogus Sociorum Missionis Federatae Societatis Jesu, 1808 (Woodstock: Ex Typis Collegii Ss. Cordis, 1887); Catalogus Sociorum Missionis Federatae Societatis Jesu, 1809 (Woodstock: Ex Typis Collegii Ss. Cordis, 1887). The first temporal coadjutor to join the mission was Joseph Mobberly in 1809. The Maryland mission paid all of Mobberly's expenses at Georgetown during his time there as a student.

${ }^{11}$ On Kenney's visitations to Maryland and Missouri in 1831-32, see Robert Emmett Curran, "Peter Kenney: Twice Visitor of the Maryland Mission (1819-1821, 1830-1833) and Father of the First Two American Provinces," in With Eyes and Ears Open: The Role of Visitors in the Society of Jesus, ed. Thomas M. McCoog, S.J. (Boston: Brill, 2019), 191-213; Gilbert J. Garraghan, S.J., The Jesuits of the Middle United States, Vol. 1 (New York: America Press, 1938), 311-30; Thomas Morrissey, Peter Kenney, S.J., 1779-1841: The Restoration of the Jesuits in Ireland, England, Sicily, and North America (Washington, DC: Catholic University of America Press, 2014), 271-313.

${ }^{12}$ Charles Plowden to Peter Kenney, June 12, 1819, cited in Cornelius Michael Buckley, S.J., Stephen Larigaudelle Dubuisson, S.J., and the Reform of the American Jesuits (Maryland: University Press of America, 2013), 94. 
institutions. ${ }^{13}$ Nevertheless, historians of Jesuit slaveholding in Maryland have seldom scrutinized how the Jesuits documented their enslaved community. ${ }^{14}$ Instead of inspecting financial records that detail the existence of hundreds of persons owned by the Society in Maryland, they have focused on documents such as the pro-slavery treatise of Br. Joseph Mobberly to understand what the Jesuits thought about enslaved persons. ${ }^{15}$ However, financial records hold a trove of information that reveals as much about Jesuit pro-slavery thought as the writings of inconsequential members of the mission.

\section{Recordkeeping Practices during the Early Years of the Maryland Mission, $1717-73$}

Adversity, itinerary work, and persecution were the distinctive features of the Jesuits' missionary life in Maryland during the early eighteenth century. This period saw the emergence of Jesuit slaveholding, as fathers transitioned from using Catholic indentured servants as plantation laborers to enslaving persons imported into the colony to produce tobacco in their estates scattered across Maryland. This transition occurred within a context of increased anti-Catholic regulations by the Maryland assembly, including levies on Catholic servants and a crackdown on the

\footnotetext{
${ }^{13}$ On archives as places of knowledge, see Markus Friedrich, The Birth of the Archive: A History of Knowledge, trans. John Noël Dillon (Ann Arbor: University of Michigan Press, 2018). On Jesuit accounting practices, see Paolo Quattrone, "Governing Social Orders, Unfolding Rationality, and Jesuit Accounting Practices: A Procedural Approach to Institutional Logics," Administrative Science Quarterly 60 (2015): 411-45; Quattrone, "Accounting for God: Accounting and Accountability Practices in the Society of Jesus (Italy, XVI-XVII Centuries," Accounting, Organizations, and Society 29 (2004): 647-83; Markus Friedrich, "Archives as Networks: The Geography of Record Keeping in the Society of Jesus (1540-1773)," Archival Science 10 (2010): 285-98.

${ }^{14}$ On Jesuit slaveholding in Maryland, see Edward F. Beckett, "Listening to Our History: Inculturation and Jesuit Slaveholding," Studies in the Spirituality of Jesuits 28, no. 5 (1996); Curran, "'Splendid Poverty," 125-46; Peter C. Finn, S.J., "The Slaves of the Jesuits of Maryland" (MA thesis, Georgetown University, 1974); Robert K. Judge, S.J., "Foundation and First Administration of the Maryland Province," Woodstock Letters 88, no. 4 (1959): 376-406; Thomas Murphy, S.J., Jesuit Slaveholding in Maryland, 1717-1838 (New York: Routledge, 2001).

${ }^{15}$ Mobberly's pro-slavery writings have been the focus of multiple authors on Jesuit slaveholding. However, their focus on his writings overestimates his importance in mission affairs. He is often portrayed as representative of Jesuit pro-slavery thought when in fact he was shunned from mission affairs and moved from different plantations because of his behavior. It is misleading to think that a brother with those characteristics could set the intellectual basis for Jesuit thought on slavery. However, there is evidence that he made his views known to mission authorities. For Mobberly's writings, see "Slavery or Cham," part 2 of diary, August 1823, Box 1, Folder 2, Joseph Mobberly Papers, Booth Family Center for Special Collections, Lauinger Library, Georgetown University. On Mobberly's correspondence with the authorities of the mission, see Mobberly's note to Grassi, Box 40, Folder 10, MPA; Mobberly to Grassi, February 5, 1815, Box 58, Folder 6, MPA. For an analysis of Mobberly's writings, see Thomas Murphy, "Brother Joseph Mobberly and the Intellectual Antecedents of Jesuit Anti-abolitionism," in Jesuit Slaveholding, 129-62; Beckett, "Listening to Our History"; "Brother Mobberley's Diary," Woodstock Letters 32, no. 1 (September 1903): 1-23.
} 
importation of Catholic indentured servants in $1715 .{ }^{16}$ These new regulations suggested further state intervention against Catholics in an increasingly hostile environment. These threats likely served as motivation for more detailed accounting practices in the Jesuit estates, as a lack of documentation could lead to the loss of the properties that financed their mission.

The first record of the Jesuits' enslaved community occurred in 1717 amid growing fears of government confiscation of their properties. It was a financial document where Fr. William Hunter, the head of the Jesuit mission in Maryland, sold for ten shillings a plantation called "Britton's Neck" to a layperson named Thomas Jameson. ${ }^{17}$ The transaction between Hunter and Jameson named fifteen persons who were sold along with church and household items. The names of Will, Jack, Kitt, Peter, Mary, Teresa, Clare, Peggy, Jack, Clemm, Tom, James, Betty, Cath, and Susan are listed along with four frying pans, two handsaws, axes, milk pans, pillows, cows, sheep, horses, and wagon carts. ${ }^{18}$ According to Thomas Murphy, this deed was “a legal maneuver, designed to save Hunter's property from possible confiscation by an anticlerical colonial government." Increasing anti-Catholic regulations in the region forced Hunter to cede his estate to a trusted layperson who would hold it until the threats against Jesuit properties subsided. ${ }^{19}$ The names of these fifteen persons owned by the Jesuits only became a matter of record because they were property that could be lost in a confrontation with authorities.

Since the first years of Jesuit slaveholding, an enslaved person was a matter of record in detail only when their status as property was the purpose of the document. The 1717 deed of gift is an example of this pattern. Hunter's transaction with Jameson included names, ages, and genders of the persons owned by the Jesuits because it was integral to document transactions in records that could pass the scrutiny of the colonial state. They did not record the recovery of this property. However, the estate appears in Hunter's will six years after the transaction with

\footnotetext{
${ }^{16}$ On the anti-Catholic regulations in Maryland during the period, see Timothy W. Bosworth, "AntiCatholicism as a Political tool in Mid-Eighteenth-Century Maryland," Catholic Historical Review 61 (1975): 539-63; Gerald Fogarty, S.J, "Property and Religious Liberty in Colonial Maryland Catholic Thought," Catholic Historical Review 71 (1986): 573-600; Gerald Fogarty, "The Origins of the Mission, 1634-1773," in Robert Emmett Curran, S.J., Gerald Fogarty, S.J., and Joseph T. Durkin, S.J.,, The Maryland Jesuits, 1634-1833 (Baltimore: Maryland Province of the Society of Jesus, 1976), 9-27. On the emergence of Jesuit slaveholding, see Murphy, Jesuit Slaveholding, 332.

17 "Britton's Neck" was the location of one of the earliest Jesuit plantations. An adjacent part of this estate became known as Newtown plantation. For the early history of the estate, see Robert Emmett Curran, Papist Devils: Catholics in British America, 1574-1783 (Washington, DC: Catholic University of America Press, 2014); Edward I. Devitt, S.J., "History of the Maryland-New York Province-III-Newtown-Leonardtown (1668-1874-1916)," Woodstock Letters 56, no. 1 (February 1, 1932): 11-25.

18 "Deed of Gift between William Hunter, S.J., and Thomas Jameson, January 30, 1717," Box 27, Folder 2, MPA.

${ }^{19}$ Murphy, Jesuit Slaveholding in Maryland, 35.
} 
Jameson. ${ }^{20}$ As the risk of a property dispute or state interference was minimal, Hunter did not record the names of the persons he enslaved at that estate. He did not explicitly bequeath any slaves to his heir George Thorold, S.J. He simply stated that he we would leave him "all real and personal estate." ${ }^{21}$ Details concerning the enslaved community were unnecessary if the property was not at risk.

Without pressure from the colonial state, the Jesuits were sporadic bookkeepers who rarely made their enslaved community a matter of record. Decades elapsed between documents that mention enslaved persons. At Britton's Neck, there was a lapse of forty-three years between documents identifying its enslaved community by name. After Hunter's deed of 1717, the next record mentioning individuals is a census from around 1760. This document, written by Fr. Arnold Livers, shows the presence of fourteen persons held in bondage at the estate, which was now named Newtown. It is a sheet full of arithmetic and lists of produce. Amid blotted ink, it reveals that fourteen enslaved persons lived in two groups of seven in a "house" and "the quarter." 22 The list also suggests marriage bonds between individuals and mentions them all by name, dividing them by gender in some instances. ${ }^{23}$ In its current state, it is nearly illegible. The Jesuits did not take care to preserve it in the same manner as other records such as the hire of enslaved persons from tenants during the harvest. ${ }^{24}$

The itinerant nature of missionary work in Maryland meant that priests traveled constantly and changed missions. This mobility had consequences for recordkeeping, as the constant travel resulted in scattered and fragmented registers of sacraments and births. Moreover, the idiosyncrasies of one record-keeper could extend into other missions, causing a crosspollination of accounting practices. After leaving Newtown, Livers led St. Inigoes plantation from 1760 to 1767. During his stay in that mission, he registered in the back of an almanac the names of twenty persons who were probably part of St. Inigoes' enslaved community. ${ }^{25}$ Just as in the case of Newtown, he connected names suggesting bonds of marriage and put others in brackets, suggesting familial bonds such as parentage. ${ }^{26}$ However, since these lists were for the internal use of the mission, they lack the details of documents such as transactions and tax records.

\footnotetext{
${ }^{20}$ Will of William Hunter, August 16, 1723, Box 25, Folder 10, MPA.

${ }^{21}$ Will of William Hunter, August 16, 1723, Box 25, Folder 10, MPA.

22 "Blotter inside Newtown Daybook, 1766-1795," Box 44, Folder 4, MPA.

${ }^{23}$ The names of the enslaved community at Newtown according to Fr. Ashby were Ben, Tessa, Beck, Rhoda, Clem, Judy, Xavier, Jem, Joe, Jack, Sam, Old Ben, Nelly, Ruth, and Clare. See "Blotter inside Newtown Daybook, 1766-1795," Box 44, Folder 4, MPA.

24 "Newtown Daybook, 1766-1795," Box 44, Folder 4, MPA.

${ }^{25}$ The names of the persons held in slavery at St. Inigoes were Matthew, Thomas, Necy, Will, Abram, Peter, James, Abram, Charles, Walter, Betty, Susan, Briget, Bess, Ann, Suckey, Mary, Martha, and Henny. See "Almanac," Box 3, Folder 15, MPA.

26 "Almanac," Box 3, Folder 15, MPA.
} 
Apart from financial records, sacramental registers and lists of births were the main documents produced by the Jesuits about their enslaved community. During the eighteenth century, the missions kept distinct lists of births of children born into slavery at four different plantations. These lists were independent from parish records. Jesuits often recorded these births in financial ledgers, emphasizing the nature of enslaved children as property. In the case of Bohemia, Jesuits registered births in their daybook along with financial transactions. ${ }^{27}$ At Port Tobacco, Fr. George Hunter registered the birth of at least fifty-one children born into slavery between 1755 and 1777. His list was written in a pigskin book containing land and property records, permissions, baptisms, births, and deaths on the mission. ${ }^{28}$ It is the oldest document to suggest parental ties within the enslaved community. At Newtown and St. Joseph's on the Eastern Shore, Fr. Joseph Mosley recorded the birth of thirty-six children born into slavery between 1752 and 1770. Mosley registered parentage and marriage ties along with the years of birth for the children in a set of scattered lists. ${ }^{29}$

These lists of enslaved children served to account them as property, to record their christening, and to mark them as dead or sold. They were inventories more than registers for sacraments. The Jesuits used these lists as a basis for their reports of an estate's population to Rome. They also used them to mark some children as sold. ${ }^{30}$ In 1765, Mosley listed eight enslaved persons residing at St. Joseph's on the Eastern Shore. Their ages ranged from fifty-five years old to two years of age. The oldest, Nanny, was listed as a "guinea negroe," linking the Maryland Jesuits to the transatlantic slave trade. ${ }^{31}$ For the rest of the persons listed, Mosley jotted down specific birth dates. These records reveal names, birth dates, deaths, and movements of persons. They mention the name of the first child born into slavery at the plantation and account for the sale of a person. ${ }^{32}$ Although they follow the same recording pattern as other plantations such as Newtown, they are more specific than most accounts of the mission during this period.

\footnotetext{
27 "Bohemia Accounts, 1735-1561" [Oversize Box 1], MPA.

28 "Property Records of the Society," Box 3, Folder 8, MPA.

29 "Fr. George Hunter's Report on the Maryland Mission, 1765." Box 57, Folder 1, MPA. "Newtown Daybook, 1766-1795," Box 44, Folder 4, MPA. The names of some of the individuals born in the 1770s appear on an informal census of Newtown, where the plantation daybook lists twenty-six persons held in slavery in 1791. See "Slaves at Newtown," Blacksmith Accounts Ledger, Box 44, Folder 1, MPA.

30 "Fr. George Hunter's Report on the Maryland Mission, 1765." Box 57, Folder 1, MPA. "Newtown Daybook, 1766-1795," Box 44, Folder 4, MPA.

31 “St. Joseph's Account Book, 1764-1767," Box 49, Folder 2, MPA.

32 “St. Joseph's Account Book, 1764-1767," Box 49, Folder 2, MPA; Mosley’s Day Book, January 18, 1765, Box 1, Folder 17, Joseph Mosley Papers, S.J. (GAMMS25) (hereafter JMSP), Georgetown University Manuscripts, Booth Family Center for Special Collections, Georgetown University.
} 
The specificity of these records was likely related to St. Joseph's status as a new household within the mission. This estate was an inhospitable missionary outpost begun by Mosley in 1765. Its foundation required the movement of enslaved persons from the White Marsh plantation. ${ }^{33}$ The movement of members of White Marsh's enslaved community to St. Joseph's was a transfer of property that needed to be recorded. The Jesuits reported the creation of new outposts to Rome and in their internal documents. ${ }^{34}$ Because of the dire conditions of this outpost, accounting appears to have been essential for the management of St. Joseph's. In his letters to his sister in England, Mosley recalls the harsh realities of his budding mission, the lack of funds, the burdens of his travels, and the composition of his mission. Mosley's attention to detail was a result of his interest in the success of the mission and the need to account to other Jesuits the loss or gains of a household in its early stages. $^{35}$

Enslaved persons were essential to the expansion of Catholicism in Maryland. Their labor financed the Jesuits' mission, and, for many months, they represented the majority of the baptisms and christenings done by the Jesuits. However, records reveal a racial distinction in recording sacraments. The sacraments of persons enslaved by the Jesuits were seldom recorded in parish books. Children born into slavery at the Jesuit plantations often only appear in financial records. Persons kept in bondage in the parish did not fare any better than the Jesuits' enslaved community. Priests recorded the names of enslaved persons they baptized and christened infrequently. In one of his registers, Mosley wrote that "from 8 Nov 1773 to 23 April 1774 christened many negroes, no whites." ${ }^{36}$ Meanwhile, the Jesuits' bookkeeping practices for the white population in their parishes were often more detailed than those for enslaved persons. ${ }^{37}$ Mosley's baptismal and marriage

\footnotetext{
${ }^{33}$ George Hunter, "Maryland Missions, 1765," Box 57, Folder 1, MPA; "St. Joseph's Account Book, 1764-1767," Box 49, Folder 2, MPA; Beckett, "Collaborators in Mission," in "Listening to Our History," 13-14; Robert Emmett Curran, "Joseph Mosley and the Eighteenth-Century Mission," in American Jesuit Spirituality: The Maryland Tradition, 1634-1900 (New York: Paulist Press, 1988) 100-24.

${ }^{34}$ George Hunter, "Maryland Missions, 1765," Box 57, Folder 1, MPA.

${ }^{35}$ For Mosley's accounts to his relatives, see Fr. Joseph Mosley to Michael Mosley, S.J., December 22, 1764, Box 1, Folder 6, JMSP; Joseph Mosley, S.J., to Mrs. Dunn, September 1, 1759, Box 1, Folder 2, JMSP, Joseph Mosley, S.J., to Mrs. Dunn, October 5, 1760, Box 1, Folder 5, JMSP; Joseph Mosley, S.J., to Mrs. Dunn, October 14, 1766, Box 1, Folder 7, JMSP, Joseph Mosley, S.J., to Mrs. Dunn, June 6, 1772, Box 1, Folder 9, JMSP. For Mosley's ministry and the history of the mission, see Curran, American Jesuit Spirituality, 100-24.

36 "Records Ordo Baptizatorum," Box 4, Folder 4, MPA.

37 "Records Ordo Baptizatorum," Box 4, Folder 4, MPA; "Transcript of Marriage Register of Joseph Mosley, S.J., and John Bolton, S.J., 1763-1802," Box 31, Folder 4, MPA; "Diary of James Walton, S.J.," Box 4, Folder 3, MPA.
} 
records for white persons at St. Mary's County offer information such as godparents, other persons present at the sacrament, age, and relatives. ${ }^{38}$ All information that he rarely noted for persons held in bondage.

The Jesuits' haphazard records during the early years of the mission circumscribed enslaved persons' documentary traces to multipurpose financial and sacramental entries. These documents served to account the Jesuits' property holdings, to protect their property from state intervention, and to inventory their plantations' daily operations. In sum, they reflect the nature of persons as property, juxtaposing the reality of an enslaved person as chattel and as an individual. As a result, they only offer approximations as to the composition of the enslaved community during the early years of the mission, and they reveal next to nothing about the everyday lives of the persons held in bondage. However, the Jesuits' archival practices were sensitive to increased internal and external pressures, with events such as the suppression of the order and the American Revolution bringing a transformation into the bookkeeping style of the Catholic priests of Maryland.

\section{The Transformation of Bookkeeping by the Corporation of Roman Catholic Clergymen, 1773-1814}

The Society's suppression in 1773 and the transfer of its properties to a corporate body transformed the recordkeeping practices of the Catholic priests who led slaveholding plantations in Maryland. After the dissolution of the Society, the twentyone missionaries of the Maryland mission signed an act of submission to the brief of suppression, bounding themselves "to a new form of ecclesiastical government" as secular priests. ${ }^{39}$ These missionaries remained in their posts, discharging their pastoral duties and often neglecting the records of the management of their missions. For close to ten years, they remained independent and disorganized, until 1783, when, at the behest of Fr. John Carroll, they organized with the purpose of "preserving in the same hands the property of the Houses of the Society." 40 Confronted with the realities of other former members of the order who were deprived of their properties and possessions after their expulsion from multiple territories, the priests in Maryland exploited the lack of secular authorities in the area to create

\footnotetext{
38 "Records Ordo Baptizatorum," Box 4, Folder 4, MPA.

39 Thomas Hughes, ed., History of the Society of Jesus in North America, Colonial and Federal Documents, Vol. 1: Part II; Nos. 141-224 (1605-1838) (Cleveland: Burrows Brothers Company, 1910), 606; "Act of Submission to the Brief of Suppression, 1774," in Hughes, History of the Society, Vol. 1: Part II, 607.

40 "John Carroll's Plan for Organizing the Mission," Box 2, Folder 2, MPA.
} 
a corporate body to preserve their "estates from alienation, waste and misapplication." 41

As a result of this revolution in episcopal governance, the Catholic priests of Maryland formed a chapter of the clergy that emphasized the importance of bookkeeping to save their properties, including the persons they held in bondage. ${ }^{42}$ They maintained an emphasis on accountability and resolved to create a committee "to assort and file all land papers," which were to be kept "in a safe place, numbering the same according to their dates." 43 The new procurator of their association expected each estate to make a regular report to the board on the state of the temporalities in their charge. ${ }^{44}$ This new system consolidated into a corporate entity with power over temporal affairs and demands over the estates by 1792, increasing the importance of bookkeeping for the survival of the Catholic mission in Maryland. ${ }^{45}$

The priests' interest in preserving and managing their assets in case of the "possible restauration of the Society" encouraged them to keep fastidious accounts

41 "John Carroll's Plan for Organizing the Mission," Box 2, Folder 2, MPA. Carroll described expelled Jesuits across the world as orphans "deprived of any share in the administration of their ancient possessions." See John Carroll, "Proposals for Management and Perpetuation of the Jesuit Estates in Maryland and Pennsylvania," MPA, Box 2, Folder 5; John Carroll, "Narrative of the Proceedings of the Suppression in Two English Jesuit Colleges," MPA, Box 2, Folder 7. For some of the news that reached the mission, see "Lettere [1774-85?] nove del Pre. G. Cordara sopra l'abolizione della Compagnia," MPA, Box 1, Folder 15; "De rebus sociorum provincia Aragonia S.J. $\mathrm{Ab}$ indicto ipsis ex Hispania exilis [...]," MPA, Box 1, Folder 16; "Account [in English] of the Suppression in France of the Jesuits by Parlement and Louis XV," MPA Box 1, Folder 16. For an overview of the multiple expulsions of the Jesuits across the world, see Maurice Whitehead, "From Expulsion to Restoration: The Jesuits in Crisis, 1759-1814," Studies: An Irish Quarterly Review 103, no. 412 (Winter 2014/15): 447-61; and Magnus Möner, "The Expulsion of the Jesuits from Spain and Spanish America in 1767 in Light of Eighteenth-Century Regalism," Americas 23, no. 2 (October 1966): 156-64.

${ }^{42}$ On the organization of Catholic priests in Maryland after the suppression of their order, see Ronald A. Binzley, "Ganganelli's Disaffected Children: The Ex-Jesuits and the Shaping of Early American Catholicism, 1773-1790," U.S. Catholic Historian 26, no. 2, Catholics in the Colony of Maryland and the Early Republic (Spring 2008): 47-77, here 59. Binzley names this process "ecclesiastical nationalism." See also Robert Emmett Curran, "Ambrose Maréchal, the Jesuits, and the Demise of Ecclesial Republicanism in Maryland, 1818-1838," in Shaping American Catholicism: Maryland and New York, 1805-1915 (Washington, DC: Catholic University of America Press, 2012), 13-29; Catherine O'Donnell, "John Carroll and the Origins of an American Catholic Church, 1783-1815," William and Mary Quarterly 68, no. 1 (January 2011): 101-26.

43 "Proceedings of the Chapter, November 23, 1786," Box 2, Folder 6, MPA.

44 "Forms of Government of the General Chapter, October 11, 1784," Box 2, Folder 5, MPA.

${ }^{45}$ On the creation of the corporation and the organization of Catholic Maryland during the suppression, see "Proceedings of the Chapter, May 14, 1789," Box 2, Folder 6, MPA; "Act of Assembly, Maryland: The Charter, 23, Dec., 1792," in Hughes, History of the Society, Vol. 1: Part II, 722-25; Murphy, Jesuit Slaveholding, 65-74; Brother Thomas W. Spalding, The Premier See: A History of the Archdiocese of Baltimore (Baltimore: Johns Hopkins University Press, 1989), 25-28; Raymond A. Schroth, "Death and Resurrection: The Suppression of the Jesuits in North America," American Catholic Studies 128 (2017): 51-66; Catherine O'Donnell, "John Carroll, the Catholic Church, and the Society of Jesus in Early Republican America," in Jesuit Survival and Restoration: A Global History, 1773-1900, ed. Robert A. Maryks and Jonathan Wright (Leiden: Brill, 2014), 368-87. 
in their plantations. ${ }^{46}$ Managers were expected to report to the procurator income, expenses, transactions, and information such as the quantity of supernumerary slaves. ${ }^{47}$ To benefit the financial health of the estate, managers recorded inventories of persons incapable of work with the purpose of "sell[ing] them to the best advantage" of their estates. ${ }^{48}$ Overall, there was a renewed interest in quantification that guided the accounting practices of estate managers. For example, at Bohemia, Fr. Francis Beeston kept a daybook to aid him in the management of the estate. This financial ledger offers day-to-day recollections of farm activities and reveals the priests' increased interest in quantifying and documenting expenses, goods, and events related to the persons they kept in bondage.

Beeston recorded information on the amount of clothing provided to each enslaved person per year, their food provisions and the distribution of goods such as blankets between enslaved families. ${ }^{49}$ Along with annotations on the weather, crop production, and work activities, he also registered multiple sales and purchases of enslaved persons and significant events such as the arrival of a shoemaker to mend the shoes of the enslaved community or the hiring of a housekeeper. ${ }^{50}$ One of those significant events recorded by Beeston was the visit from a medical practitioner, Dr. Matthews, who on February 22, 1791 vaccinated for smallpox twenty enslaved persons. These individuals formed the enslaved community at Bohemia. Their names were Bill, Barny, Stephen, Kate, Dick, Suke, Charles, Jack, Henny, Lucy, Fanny, Jenny, Dennis, James, Patrick, Amelia, Nelly, John, Joseph, and Ralph. Many of them had been enslaved by the Jesuits before the suppression. ${ }^{51}$

The enslaved community's activities and their use of time were two aspects of plantation life under scrutiny at Bohemia. In many plantations in the Chesapeake, enslaved persons were allowed to keep a plot of land to work on Sundays, growing subsistence crops to earn a small amount of money. ${ }^{52}$ At Bohemia, Beeston wrote

\footnotetext{
46 "Proceedings of the General Chapter, November 6, 1783," Box 2, Folder 5, MPA.

47 ““'Backmatter,' Bohemia Day Book, 1790-1799," Box 1, Folder 1, Maryland Province Collection (hereafter MPC), Booth Family Center for Special Collections, Lauinger Library, Georgetown University.

${ }^{48}$ For an example of an inventory based on work capabilities, see "Inventory of Slaves Incapable of Work," Box 29, Folder 2, MPA. On the sale of supernumerary slaves, see "Proceedings of the General Chapter at White Marsh, May 11, 1789," Box 2, Folder 6, MPA.

${ }^{49}$ On the sale of enslaved persons in the day book, see "Negroes Sold, 1793-1794," Bohemia Day Book, Box 1, Folder 1, MPC. The managers of Bohemia plantation also registered sales in the estate's financial ledger; see entries July 2, 1790, July 5, 1790, September 1790, January 1791, February 1791, February 1792, March, 1792, January 1792, February 1795, "Bohemia Plantation Ledger, 1790-1870," Box 49, Folder 3, MPA.

50 "Entry February 24, 1791," Bohemia Day Book, Box 1, Folder 1, MPC; "March 21, 1791," Bohemia Day Book, Box 1, Folder 1, MPC.

51 "Entry February 22, 1791," Bohemia Day Book, Box 1, Folder 1, MPC.

52 "October 1792: NB Dimensions Garden Patch," Bohemia Day Book, Box 1, folder 1, MPC. For examples of transactions between the enslaved community and the Catholic priests of the plantation, see "February 1791," "September 1791." "October 1791," "December 1791," "January 1792,"
} 
strict regulations on this matter, determining that "both men and women were allowed a patch of at least 100 yards long and 40 yards wide." Married men had access to larger plots of land if their wives lived at Bohemia plantation. ${ }^{53}$ Children had no access to plots until "he or she [were] a full hand, with respect to work." On Sundays, Beeston usually recorded on his ledger when the enslaved community used these garden patches. ${ }^{54}$ Sometimes he registered what was grown in them. The plantation's daybook and its account book are full of transactions involving crops grown by enslaved persons. ${ }^{55}$ The priests' interest in tracking their assets, land, and their enslaved community resulted in highly detailed bookkeeping that encompassed multiple aspects of plantation life. These books also reveal an interest in control, efficiency, and management not seen before the suppression of the Jesuit order.

The growth of the Catholic Church in America was one of the factors driving the need for efficiency and detailed bookkeeping in plantations such as Bohemia. Before 1793, the members of the corporation were the only Catholic priests in the United States. However, as the needs of the church grew, members of the Society of St. Sulpice arrived in the United States from France at the behest of Carroll, the leader of the corporation and the first bishop of Baltimore. The Sulpicians' purpose was to establish a seminary in Baltimore. ${ }^{56}$ To aid them in that endeavor, in 1793 the corporation granted to the seminary of St. Sulpice the profits of Bohemia plantation "for the maintenance of the superior and directors of the

\footnotetext{
"February 1792," "Bohemia Plantation Ledger, 1790-1870," Box 49, Folder 3, MPA. On the presence of garden patches in plantations, see Hilary Beckles, "An Economic Life of Their Own: Slaves of Commodity Producers and Distributors in Barbados," in The Slavery Reader, ed. Gad Heuman and James Walvin (New York: Routledge, 2003), 507-21; Roderick A. McDonald, "Independent Economic Production by Slaves on Antebellum Louisiana Plantations," in Heuman and Walvin, Slavery Reader, 486-505.

53 “October 1792: NB Dimensions Garden Patch,” Bohemia Day Book, Box 1, Folder 1, MPC.

${ }^{54}$ The Jesuits got permission from authorities in Europe to be exempted from the requirement that Catholics rest on holidays, including Sundays. This allowed them to force their enslaved community to do manual labor on Sundays. See "Regulations Regarding the Observance of Holy Days by Maryland Catholics, 1722," Box 2, Folder 9, MPA.

${ }^{55}$ For examples of transactions between Catholic priests and their enslaved community, see "Feb., 1790," Bohemia Ledger, 1790-1870, Box 49, Folder 3, MPA; “October, 1791,” Bohemia Ledger, 1790-1870, Box 49, Folder 3, MPA; "December 1791," Bohemia Ledger 1790-1870, Box 49, Folder 3, MPA; "January, 1792," Bohemia Ledger, 1790-1870, Box 49, Folder 3, MPA; "September 1796," Box 49, Folder 3, MPA.

${ }^{56}$ On the Sulpicians' arrival in Maryland, see George M. Barringer, "They Came to Georgetown: The French Sulpicians," Georgetown Today (July 1977): 7-8; Robert Emmett Curran, The Bicentennial History of Georgetown University: Volume 1; From Academy to University, 1789-1889 (Washington, DC: Georgetown University Press, 1993), 47-51; Kyle Roberts and Stephen R. Schloesser, eds., Crossings and Dwellings: Restored Jesuits, Women Religious, American Experience, 1814-2014 (Boston: Brill, 2017), 381-84; Charles G. Herbermann, The Sulpicians in the United States (New York: Encyclopedia Press, 1916); Joseph Ruane, The Beginnings of the Society of St. Sulpice in the United States, 1791-1829 (Washington, DC: Catholic University of America Press, 1935).
} 
seminary." ${ }^{57}$ The seminary was a sorely needed enterprise that could not be undertaken by the members of the corporation who were invested in the growth of their newly founded academy, Georgetown College. The agreement between the Sulpicians and the corporation was part of the bishop's plan to extend Catholicism in America. ${ }^{58}$

As a result of this agreement, Bohemia became an estate that required accounts for two different authorities: the Sulpicians and the corporation. As two distinct institutions became involved in the property holdings of the Catholic Church, there was a renewed need for detailed records and accounting. This duality in Bohemia's administration required additional overseeing in the plantation. Both the corporation and the Sulpicians kept distinct records of the activities in the plantation. ${ }^{59}$ For a period of time, authorities from both groups were present in the mission. ${ }^{60}$ However, the growth of the church required movement of personnel, and eventually the corporation members left Bohemia. The estate was left under the daily management of the Sulpicians, whose only obligations were that they maintained a "clergyman on the estate for the benefit of the neighboring congregation" and discharge the standing debts of the mission. ${ }^{61}$

The Sulpicians at Bohemia were less detailed record-keepers than the members of the corporation who had managed the plantation before their arrival. During the first months of their management of the estate, they exclusively documented their activities in scattered annotations in French. Moreover, there was a constant change of bookkeepers as some Sulpicians divided their time between the plantation and activities in the Baltimore seminary. ${ }^{62}$ This change in personnel resulted in a lapse in bookkeeping from October 1793 to early 1796, when Ambrose Maréchal, a Sulpician who had briefly assisted Beeston in the management of the

\footnotetext{
57 “Agreement between Fr. Molyneux and Fr. Nagot, May 2, 1793," in Hughes, History of the Society, Vol. 1: Part II, 748.

${ }^{58}$ See John Carroll to Lord Arundell, October 4, 1790, Box 3, Folder 6, MPA; John Carroll to Charles Plowden, October 12, 1791, Box 3, Folder 6, MPA; Ruane, Beginnings; Barringer, "They Came to Georgetown," 7; Edward I. Devitt, "Bohemia: Mission of St. Francis Xavier, Cecil County, Maryland," Records of the American Catholic Historical Society 23 (June 1913): 97-139. On the Sulpician management of Bohemia, see Thomas R. Ulshafer, P.S.S., "Slavery and the Early Sulpician Community in Maryland," U.S. Catholic Historian 37, no. 2 (Spring 2019): 1-21.

${ }^{59}$ For Sulpician bookkeeping at Bohemia, see Ulshafer, Slavery, 6-7, 13.

${ }^{60}$ The first Sulpician arrived at Bohemia on December 15, 1792. Fr. Ambrose Maréchal joined Fr. Francis Beeston at the plantation. On May 18, 1793, Beeston left Bohemia and was replaced by Charles Sewall in charge of the congregation and the first Sulpician manager of the estate, Fr. Lewis Caesar Delavan. See "Entries December 15, 1792," "May 18, 1793," Bohemia Day Book, Box 1, Folder 1, MPC; "Note of Fr. Peter Kenney, Visitor, on the Debt of Bohemia, 1790, and Changes of Personnel, 1790-1793," in Hughes, History of the Society, Vol. 1: Part II, 748.

61 "Agreement between Fr. Molyneux and Fr. Nagot, May 2, 1793," in Hughes, History of the Society, Vol. 1: Part II, 748. Devitt, Bohemia, 97-139.

${ }^{62}$ On the Sulpician personnel during their first months as sole managers of Bohemia, see Ulshafer, Slavery, 13; Devitt, Bohemia, 122-28. "Entries June 1793-1796," Bohemia Day Book, 1790-99, Box 1, Folder 1, MPC.
} 
plantation, returned to Bohemia after recovering from a bout of malaria. Upon his return, Maréchal began to focus on optimizing the plantation's management. He created lists for harvest-picking, counted the hands that labored any given day, and continued Beeston's accounting practices of listing the plantation's enslaved population and the goods used for their maintenance every year. ${ }^{63}$

This focus on the status of the plantation's property holdings was probably one of the reasons that led Maréchal to record an act of violence at the plantation. On September 2, 1797, Maréchal wrote in the plantation's daybook that " $\mathrm{Mr}$ Thomas O'Donald violently assaulted Old Davy."64 Davy had been enslaved at Bohemia since at least 1791. O'Donald was a tenant who often rented enslaved persons from Bohemia's priests and who on occasions acted as an overseer. ${ }^{65}$ This attack had the possibility of risking either a loss of property or a business acquaintance. Maréchal's subsequent entries suggest that business was on his mind, as he recorded afterward some business dealings with the O'Donald family and the seeding and sowing of the plantation's land. ${ }^{66} \mathrm{He}$ never recorded the reasons for the attack or Davy's state afterward. ${ }^{67}$

At the time of Maréchal's entries on Davy's attack, the Corporation of Roman Catholic Clergymen and the Sulpicians at Bohemia plantation were embroiled in a dispute over the profits of the estate. One of the reasons for this dispute was the distribution of resources emanating from the slave trade. After taking sole management of the plantation, the Sulpicians quickly began to sell persons, including a three-week-old infant named Nell. In a span of thirteen months, they sold three more children and four adults. ${ }^{68}$ As a result of these sales, the corporation wrote to the president of the seminary at Baltimore to remind him that "the moneys arising from the sale of negroes [were] not understood to be enumerated among the profits of the estate." 69

This dispute between the Sulpicians and the corporation over funds obtained from the sale of persons increased the number of records involving enslaved persons. In the aftermath of this disagreement, Maréchal enumerated the enslaved persons living in the plantation, identifying those that were the property of the estate, and those that were the property of the Sulpicians. ${ }^{70}$ During their time as

\footnotetext{
${ }^{63}$ On Maréchal's return to Bohemia, see Ulshafer, Slavery, 11-12; Backmatter, Bohemia Day Book, 1790-99, Box 1, Folder 1, MPC.

64 "Entry September 2, 1797," Bohemia Day Book, 1790-99, Box 1, Folder 1, MPC.

65 "October 1790," Bohemia Ledger, 1790-1870, Box 49, Folder 3, MPA; August 1796, Bohemia Ledger, 1790-1870, Box 49, Folder 3, MPA.

66 "Entry September 1797," Bohemia Day Book, 1790-99, Box 1, Folder 1, MPC.

67 "Entries September-October 1797," Bohemia Day Book, 1790-99, Box 1, Folder 1, MPC.

68 "Negroes Sold, since the Year 1793," Bohemia Day Book, 1790-99, Box 1, Folder 1, MPC.

${ }^{69}$ Proceedings of the Corporation of Roman Catholic Clergymen, August 21, 1795, St. Thomas's Manor, Box 24, Folder 1, MPA; Proceedings of the Corporation of Roman Catholic Clergymen, September 4, 1797, St. Thomas's Manor, Box 24, Folder 1.

70 "Census of Negroes," Backmatter, Bohemia Day Book, 1790-99, Box 1, Folder 1, MPC.
} 
stewards of Bohemia, the Sulpicians sold ten persons. They also purchased two men, a woman, and a child. Maréchal added information to this list of persons bought and sold by members of his order since 1793 and kept notes on the rental of persons belonging to the plantation. ${ }^{71}$

Sulpicians such as Maréchal believed that the labor of enslaved persons was the only financial benefit they received from the estate. ${ }^{72}$ The financial value of these persons compelled the Sulpicians to document plantation activities, especially since there was movement of persons between Bohemia and the seminary in Baltimore. In 1794, the Sulpician priest in charge of Bohemia recorded the transfer of three enslaved persons, Steven, Peg, and Jack, to the seminary in Baltimore. ${ }^{73}$ Their presence at the seminary was part of the prerogatives allowed to the Sulpicians under their agreement with the corporation. ${ }^{74}$ However, their presence in Baltimore became a matter of contention after the corporation decided to reclaim the management of Bohemia in 1799. In reaction to that decision, the Sulpicians demanded that these three persons, along with an enslaved boy at Bohemia named Jack, be given "in full possession and property" to their seminary, as "they [were] by no means necessary to the plantation," while they were "very useful to [them]."75 The squabble between ecclesiastical authorities interested in benefiting from human bondage determined the written record of these four persons at Bohemia.

Another aspect that drove plantation recordkeeping in the period of the suppression was the individual actions of enslaved persons, in particular their efforts to achieve their freedom. The Catholic priests of the Corporation of Roman Catholic Clergymen had a contentious relationship with the persons they held in bondage in their plantations. At least twenty-six enslaved persons sued priests from the Maryland mission for their freedom. ${ }^{76}$ Because of the constant litigation, managers in

\footnotetext{
71 "Negroes Sold, since the Year 1793," Bohemia Day Book, 1790-99, Box 1, Folder 1, MPC. On Maréchal's involvement in the preparation of this list, see Ulshafer, Slavery, 12-14; on the rental of enslaved persons from the plantation, see Hiring Contract, January 11, 1798, Box 30, Folder 3, MPA; "Entries July 1796," "April 1797," Bohemia Day Book, 1790-99, Box 1, Folder 1, MPC; "Entries October 1798, July 1798," Bohemia Day Book, 1790-99, Box 1, Folder 1, MPC; Backmatter, Bohemia Day Book, 1790-99, Box 1, Folder 1, MPC.

${ }^{72}$ Ulshafer, Slavery, 15. On the profits given to the seminary from Bohemia, see "Inventory, 1793," Box 16, Folder 3, MPA.

73 "July 1794," Bohemia Ledger, 1790-1870, Box 49, Folder 3, MPA; "Proceedings of the Corporation of Roman Catholic Clergymen, October 9, 1799," Box 23, Folder 10, MPA. Other entries suggest the transfer of at least one other woman who remains unnamed in the records. See "August 1794," Bohemia Ledger, 1790-1870, Box 49, Folder 3, MPA.

${ }^{74}$ Ulshafer, Slavery, 14-15.

${ }^{75}$ Fr. Nagot to the Corporation of Roman Catholic Clergymen, August 22, 1799, Box 23, Folder 9 , MPA; "Proceedings of the Corporation of the Roman catholic Clergy at St. Thomas's Manor," October 9, 1799, Box 23, Folder 10, MPA; "Notes concerning Maintenance of Sulpicians and Seminary while Occupying Bohemia," Box 16, Folder 3, MPA.

${ }^{76}$ John Ashton, Francis Neale, and Sylvester Boarman were sued by members of the Mahoney and Queen families for their freedom. For the importance of these cases in Maryland's slaveholding culture, see Eric Robert Papenfuse, "From Recompense to Revolution: Mahoney v. Ashton and the
} 
all of the Jesuit plantations attempted to keep detailed accounts of the costs of freedom suits, particularly those involving the Queen and Mahoney families who sued Fr. John Ashton. ${ }^{77}$ Priests also documented lawyer payments, court expenses, and transactions such as the payment to bribe a juror and payments to persuade a lawyer not to represent an enslaved family that had sued for their freedom. ${ }^{78}$

Amid the litigation between Catholic priests and the persons they held in bondage, plantation managers attempted to document a person's intentions to sue for their freedom and recorded their deliberations concerning possible manumissions. In 1796, Maréchal recorded at Bohemia that he was advised by Fr. Charles Sewall, the agent of the corporation, not to free an enslaved man named Ralph. As a result, Maréchal negotiated with Ralph a monthly stipend for working at Bohemia's mills. ${ }^{79}$ A year later, in 1797, an enslaved man named Patrick Barnes attempted to sue Maréchal for his freedom. Maréchal kept detailed notes on the case and settled on selling Barnes his freedom upon the payment of two hundred pounds. ${ }^{80}$ Manumissions were a point of contention within the corporation and were

Transfiguration of Maryland Culture, 1791-1802," Slavery \& Abolition: A Journal of Slave and Post-slave Studies 15, no. 3 (1994): 38-62; Will G. Thomas III, "The Timing of Queen v. Hepburn: An Exploration of African American Networks in the Early Republic," Oh Say Can You See: Early Washington, DC, Law \& Family; http://earlywashingtondc.org/stories/queen_v hepburn (accessed August 21, 2020). For access to the cases, visit the O Say Can You See: Early Washington, DC, Law \& Family, University of Nebraska-Lincoln website; http://earlywashingtondc.org (accessed August 21, 2018).

${ }^{77}$ See "Proceedings of the Corporation of Roman Catholic Clergy Held at White Marsh, July 9, 1805," Box 24, Folder 1, MPA; "Proceedings of the Corporation of Roman Catholic Clergy Held at White Marsh, May 23, 1803," Box 24, Folder 1, MPA; for the amount expended on the lawsuits, see "Agents Cashbook, 1802-1820 by Fr. McElroy," Box 69, Addenda MPA. For the conflicts between Ashton and his fellow Jesuits, see John Ashton to John Carroll, June 13, 1801, Baltimore, in Hughes, History of the Society of Jesus in North America, Part 2, 705; Bishop Carroll to Leonard Neale, July 5, 1801, Baltimore, in Hughes, History of the Society of Jesus in North America, Part 2, 706; John Ashton to the Corporation of Roman Catholic Clergymen, July 5, 1805, in Hughes, History of the Society of Jesus in North America, Part 2, 713; Papenfuse, "From Recompense to Revolution"; Thomas W. Spalding, The Premier See: A History of the Archdiocese of Baltimore, 1789-1889 (Baltimore: Johns Hopkins University Press, 1989), 43; T. Stephen Whitman, The Price of Freedom: Slavery and Manumission in Baltimore and Early National Maryland (Lexington: University Press of Kentucky, 1997), 66-67.

78 “January 1799," St. Thomas's Account Book, 1793-1821 [172 E], Box 46, Folder 6, MPA; “Entry March 8, 1797," St. Thomas's Account Book, 1793-1821 [172 E], Box 46, Folder 6, MPA; "Entry August 29, 1809," St. Thomas's Account Book, 1793-1821 [172 E], Box 46, Folder 6, MPA; "Entry November 4, 1810," St. Thomas's Account Book, 1793-1821 [172 E], Box 46, Folder 6, MPA; "October 26, 1811," St. Thomas's Account Book, 1793-1821 [172 E], Box 46, Folder 6, MPA; "June 16, 1794," St. Thomas's Account Book [172 H], 1793-1822, Box 47, Folder 2, MPA; "August 20, 1794," St. Thomas's Account Book [172 H], 1793-1822, Box 47, Folder 2, MPA; "June 5, 1800," St. Thomas's Account Book [172 H], 1793-1822, Box 47, Folder 2, MPA; "Undated 1794," St. Thomas's Account Book [172 H], 1793-1822, Box 47, Folder 2, MPA.

79 "Entry, July 1796," Bohemia Day Book, Box 1, Folder 1, MPC; February 1797, Bohemia Day Book, Box 1, Folder 1, MPC.

80 "Freedom Contract, August 15, 1797," Box 30, Folder 3, MPA; “Notes on Patrick Barnes' Petition of Freedom," Box 30, Folder 3, MPA. The Corporation of Roman catholic Clergymen discussed 
often a matter of record. Four years later, in a meeting from 1801, the corporation documented their resolution against manumitting a man named Peter who was enslaved at Conewago, a plantation in Pennsylvania. Their resolution was that "it would prove injurious" to their power over other slaves to grant Peter his freedom. The corporation instead decided to allow him to purchase his freedom. ${ }^{81}$

The Corporation of Roman Catholic Clergymen revolutionized recordkeeping in an attempt to preserve their estates, help develop the early American church, and finance their educational endeavor at Georgetown College. With varying degrees of success, they increased the documentation of their enslaved community, kept track of their movements, and to a certain extent their intentions. At the corporate level, the clergymen of Maryland were particularly successful at documenting sales and the movement of enslaved persons during the time of the suppression. During this period, the corporate body of Maryland approved and documented the movement of at least six persons between the estates, including a man named Alexius who was put "in the service of the bishop." 82 They also recorded approving the "disposal of supernumerary slaves" to "good and Christian masters," as well as the sale of at least thirteen enslaved persons. ${ }^{83}$ Their deliberations over

once more the possibility of manumitting a man named Peter in 1801 . They decided that manumission would "prove a precedent a little injurious to that of subordination, which ought to be preserved amount the other slaves belonging to the corporation." As a result, they allowed Peter to purchase his freedom. See Proceedings of the Corporation of Roman Catholic Clergymen, May 5, 1801, Newtown, Box 24, Folder 1, MPA.

${ }^{81}$ Meeting of the Corporation of Roman Catholic Clergymen, May 5, 1801, Box 24, Folder 1, MPA.

82 On the movement of enslaved persons, see "Proceedings of the General Chapter, November 1786," Box 2, Folder 6, MPA; "Proceedings of the Corporation of Roman Catholic Clergymen, St. Thomas's Manor, October 9, 1799," Box 24, Folder 1, MPA; "Proceedings of the Corporation of Roman Catholic Clergymen, White Marsh, May 23, 1803," Box 24, Folder 1, MPA; "Proceedings of the Corporation of Roman Catholic Clergymen, June 10, 1811," Georgetown College, Box 24, Folder 1, MPA; "Proceedings of the Corporation of Roman Catholic Clergymen, June 10, 1818," Georgetown College, Box 24, Folder 1, MPA. On the case of Alexius, a man kept in slavery in the service of Bishop John Carroll, see "Proceedings of the Corporation of Roman Catholic Clergymen, St. Thomas's Manor, March 29, 1797," MPA, Box 24, Folder 1; “August 15, 1796," Agent's Cashbook Kept by Francis Neale, Box 69, MPA: Addenda. “January 1797," Agent's Cashbook Kept by Francis Neale, Box 69, MPA: Addenda; “April 8, 1797," Agent's Cashbook Kept by Francis Neale, Box 69, MPA: Addenda. On Carroll's sale of Alexius, see John Carroll to James Barry, July 21, 1806, in The John Carroll Papers: Volume 2, 1792-1806, ed. Thomas O'Brien Hanley, S.J. (Notre Dame: University of Notre Dame Press, 1976), 521.

${ }^{83}$ On the sale of slaves, see "Proceedings of the General Chapter at White Marsh, May 11, 1789," Box 2, Folder 6, MPA; "Proceedings of the Corporation of Roman Catholic Clergymen, April 25, 1804, White Marsh," Box 24, Folder 1, MPA; "Proceedings of the Corporation of Roman Catholic Clergymen, May 23, 1803, White Marsh," Box 24, Folder 1, MPA; "Proceedings of the Corporation of Roman Catholic Clergymen, April 25, 1804, White Marsh," Box 24, Folder 1, MPA; "Proceedings of the Corporation of Roman Catholic Clergymen, November 28, 1804, White Marsh," Box 24, Folder 1, MPA; "Proceedings of the Corporation of Roman Catholic Clergymen, July 9-11, 1805, White Marsh," Box 24, Folder 1, MPA; "Proceedings of the Corporation of Roman Catholic Clergymen, May 12, 1808," Georgetown College, Box 24, Folder 1, MPA; "Proceedings of the Corporation of Roman Catholic Clergymen, September 4, 1808," Georgetown College, Box 24, 
the future of their property included discussing if it would "be advisable to dispose of the whole or greatest part of the slaves on their estates," 84 and they also registered allowing other members of the Roman Catholic clergy to purchase enslaved persons for their personal use. ${ }^{85}$

In their corporate discussions, the clergymen of Maryland wrote about enslaved persons as they dealt with their other assets, haggling over profits, and fighting over the rights of the disposal of their properties. ${ }^{86}$ Over the years, they continually discussed how to distribute the profits arising from the slave trade, determining that the funds gained from the sale of persons would be "appropriated to the use of the estates from which the colored people are sold." ${ }^{\prime 87}$ In the period of suppression, the priests' dependency on the sale of persons to maintain their mission increased as well as its documentation. Enslaved persons were a major source of their wealth, and thus integral to their corporate survival. However, the decision of many members of the corporate body to rejoin the Jesuit order after its partial and complete restorations in 1804 and 1814 would bring about another transformation in the recordkeeping practices of Catholic priests as they would have to contend with the presence of two institutions that attempted to oversee their financial affairs: the restored Society of Jesus and the Corporation of Roman Catholic Clergymen.

Folder 1, MPA; "Proceedings of the Corporation of Roman Catholic Clergymen, June 26, 1809," Georgetown College, Box 24, Folder 1, MPA.

${ }^{84}$ For their resolutions concerning the sale of enslaved persons and the repeal on the sale of their enslaved community, see "Proceedings of the Corporation of Roman Catholic Clergymen, May 18 19, 1813 at Georgetown College," Box 24, Folder 1, MPA; "Proceedings of the Corporation of Roman Catholic Clergymen, September 14, 1813 at Georgetown College," Box 24, Folder 1, MPA; "Proceedings of the Corporation of Roman Catholic Clergymen, June 14, 1814 at Georgetown College," Box 24, Folder 1, MPA; "Proceedings of the Corporation of Roman Catholic Clergymen, August 22, 1820 at St. Thomas's Manor," Box 24, Folder 1, MPA. For an analysis of the debate, see Murphy, Jesuit Slaveholding, 78-85.

${ }^{85}$ On the sale or rental of enslaved persons to the clergy, see "Proceedings of the Corporation of Roman Catholic Clergymen, September 4, 1808," Georgetown College, Box 24, Folder 1, MPA; "Proceedings of the Corporation of Roman Catholic Clergymen, June 26, 1809," Georgetown College, Box 24, Folder 1, MPA; "Proceedings of the Corporation of Roman Catholic Clergymen, June 10, 1811," Georgetown College, Box 24, Folder 1, MPA; "Proceedings of the Corporation of Roman Catholic Clergymen, September 14, 1813," Georgetown College, Box 24, Folder 1, MPA; "Proceedings of the Corporation of Roman Catholic Clergymen, June 14, 1814," Georgetown College, Box 24, Folder 1, MPA.

86 "Forms of Government of the General Chapter, October 11, 1784," Box 2, Folder 5, MPA; "Proceedings of the General Chapter at White Marsh, May 15, 1789," Box 2, Folder 6, MPA; "Proceedings of the Corporation of Roman Catholic Clergymen, April 10, 1793, St. Thomas's Manor," Box 24, Folder 1, MPA; "Proceedings of the Corporation of Roman Catholic Clergymen, May 23, 1803, White Marsh," Box 24, Folder 1, MPA.

87 "Proceedings of the Corporation of Roman Catholic Clergymen, June 14, 1814," Georgetown College, Box 24, Folder 1, MPA. 


\section{A Restored Society Scrutinizes the Recordkeeping of the Maryland Jesuits, 1804-67}

The restoration of the Society of Jesus in Maryland changed the course of recordkeeping at the temporalities in charge of the Corporation of Roman Catholic Clergymen. Starting in 1804, both the Society and the corporation continued to exist in Maryland, haggling over the ultimate right of property of what had been the Jesuit estates before the suppression of the order. This administrative transformation had two unintended consequences related to personnel matters. First, the incorporation of Jesuit brothers as bookkeepers improved recordkeeping at some of the missions where they were assigned. Second, the arrival of personnel from Europe added new challenges in bookkeeping, as newly arrived priests had to adapt to a new language, and a new country. As a result, at least three plantations did not keep regular accounts for several years. This diversity of personnel explains the diametrically opposite turns of recordkeeping at multiple plantations.

The entrance into the Society of two brothers, Joseph Mobberly and John McElroy, had a substantial impact on the mission's recordkeeping. McElroy, as agent of the corporation with a merchant background, kept detailed accounts of the profits derived from the sales of persons. ${ }^{88}$ During his time at Georgetown College, he also recorded a census of the population of the school, including the number of servants. ${ }^{89}$ After becoming a priest and taking the chaplaincy at Holy Trinity Church, McElroy also documented his ministry among the enslaved population of Georgetown College and its neighborhood. The detailed annotations on his diary register events such as the escape of a man named Isaac, who was later captured and sold by the Jesuits. ${ }^{90}$ His personal diaries include sacraments and burials of at least thirty-eight enslaved persons and twenty free people of color between 1819 and $1824 .{ }^{91}$ In his reminisces, he often recorded family ties between enslaved persons and vivid imagery of burials. One such example was the burial of Sucky, a woman enslaved by a Mr. Key who was buried in the college ground and whose

\footnotetext{
88 "Proceedings of the Corporation of Roman Catholic Clergymen, June 10, 1818, St. Thomas's Manor," Box 24, Folder 1, MPA

89 "Backmatter," Day Book, 1812-14 (I.A.4.d.), Georgetown College Financial Records: Vault Collection, Georgetown University Archives (hereafter GUA), Booth Family Center for Special Collections, Georgetown University; "Backmatter," Day Book, 1814-17 (I.A.4.e.), GUA.

${ }^{90}$ Entry January 29, January 30, 1814, "Fr. McElroy's Diary, January 1, 1813-August 21, 1815," Selected Papers of the Rev. John McElroy, S.J., Digital Georgetown.

91 "Persons Received in the Catholic Church 1819," Histories/Accounts, John McElroy Journals, Box 9, Folder 1, MPA.
} 
funeral McElroy recorded as being attended by "about 400 colored and other persons." ${ }^{92}$

Br. Mobberly also distinguished himself for being a comprehensive bookkeeper. Like McElroy, he was also a prolific journal writer. In Mobberly's reflections, he accused enslaved persons of cannibalism, defended slavery, and presented a dehumanizing view of the members of the enslaved community. ${ }^{93}$ Historians have often analyzed his words to study pro-slavery thought. ${ }^{94}$ However, Mobberly's accounting exposes another feature of Jesuit slaveholding: the use of accounting records to control and enumerate enslaved individuals. At St. Inigoes, Mobberly established a number system to account and denominate the plantation's enslaved population. He kept a detailed relation of shoes furnished to each enslaved person and their shoe size. ${ }^{95} \mathrm{He}$ quantified many aspects of an enslaved person's life, including the costs of their maintenance and their production on the farms. His detailed bookkeeping was driven by the need to increase the efficiency of the Jesuit plantations and their profitability. His documenting practices as well as his viciousness differentiated St. Inigoes from the sometimes-chaotic system of recordkeeping in each of the other plantations. ${ }^{96}$

McElroy's and Mobberly's bookkeeping practices were exceptions during the first years of the restored Society. In other estates, such as Bohemia, there were decade-long gaps in accounting records. At St. Thomas's Manor, the priests in charge of the mission did not record an account related to slaveholding between 1807 and 1821 . At St. Inigoes, there was little recording activity between 1816 and 1825. Newtown plantation appears to be the only one with constant entries concerning the expenditures of the mission. ${ }^{97}$ Corporation agents were also

\footnotetext{
${ }^{92}$ Entry April 10, 1819, "Persons Received in the Catholic Church 1819," Histories/Accounts, John McElroy Journals, Box 9, Folder 1, MPA.

93 "Slavery or Cham," Diary Part 2, Box 1, Folder 2, JMP. See in particular pp. 87, 89.

${ }^{94}$ Murphy, "Brother Joseph Mobberly and the Intellectual Antecedents of Jesuit Anti-abolitionism," 129-62; Beckett, "Jesuit Ministry and Racism: The Example of Mobberly," in "Listening to Our History," 20-23; "Brother Mobberley's Diary," Woodstock Letters 32, no. 1 (September 1903): 123.

95 "Distribution of Shoes at St. Inigoes, March 1818," St Inigoes Rent/Blacksmith Accounts, January 1, 1804 to December 31, 1832, Box 44, Folder 1, MPA.

96 "What the Farm Expends on Blacks," Diary Part 1, Box 1, Folder 1, pp. 139-40, JMP; "State of the Farm When I Left It," Diary Part 1, Box 1, Folder 1, pp. 131-35, JMP; Joseph Mobberly to Giovanni Grassi, February 5, 1815, Box 58, Folder 6, MPA. On Mobberly's viciousness and the accusations that led to his removal as overseer of St. Inigoes, see Randall M. Miller, "Slaves and Southern Catholicism," in Masters and Slaves in the House of the Lord: Race and Religion in the American South, 1740-1870, ed. John B. Boles (Lexington: University Press of Kentucky, 1988), 127-52; Murphy, Jesuit Slaveholding, 116-17; Craig Steven Wilder, "War and Priests: Catholic Colleges and Slavery in the Age of Revolution," in Slavery's Capitalism: A New History of American Economic Development, ed. Sven Beckert and Seth Rockman (Philadelphia: University of Pennsylvania Press, 2016), 227-42.

${ }^{97}$ Bohemia Ledger, 1790-1870, Box 49, Folder 3, MPA; "St. Thomas's Account Book, 17931822," Box 47, Folder 2, MPA; St. Inigoes Accounts, 1801-39, Box 43, Folder 3, MPA; St. Inigoes
} 
inconsistent in their mission accounts. From 1815 to 1818 , there were only sporadic reports of the mission's income. ${ }^{98}$

After the restoration, the only records prepared with relative consistency were sacramental registers. Plantations such as Newtown, Bohemia, and St. Inigoes kept regular records of baptisms, marriages, and burials of their parishes and their enslaved community. These records offer an approximation of the composition of the enslaved population in each plantation as well as the Catholic population of the parish. ${ }^{99}$ Moreover, thanks to diocesan authorities, the order documented rules about giving sacraments to enslaved persons. They established, for example, that priests had to get permission from enslavers to marry a person and that they had to promise not to separate enslaved husbands and wives. ${ }^{100}$ In the case of confession and Holy Communion, authorities determined that an enslaved woman who had run away could not receive these sacraments until she returned to her enslaver. ${ }^{101}$

However, the overall lack of recording activity, as well as nativism and the property disputes between the corporation and the Jesuits, brought intense scrutiny from Roman authorities who worried about the state of the mission. As a result, the superior general sent the Irish Jesuit Peter Kenney to American shores in 1820 to settle Maryland's brewing conflicts. ${ }^{102}$ The visitor's examination of the farms found arbitrary regulations, "complaints of bad management, unprofitable contracts, useless and expensive experiments and speculations." 103 Kenney was forced to inform the general that there was not "a regular and uniform system in keeping the books" in the Maryland mission. ${ }^{104}$

In the case of the enslaved community, Kenney recorded accusations of mistreatment, including the whipping of pregnant women and a lack of food rations in multiple plantations. Amid such despair, he established a series of regulations, such as that the enslaved community should have fixed rations. He also ordered the Maryland priests to discontinue the punishment of enslaved women, as there were reports that they had "been tied up in the priests own parlour." According to the visitor, "the crimes [...] reported [were] [...] a reproach to [the] Society." He held hope that the corporation would one day "esteem it feasible to get rid of the slaves,"

Accounts, Rents, 1816-32, Box 44, Folder 1, MPA; Newtown Accounts, 1816-23, Box 46, Folder 1, MPA.

98 “Agents Cashbook, 1802-1820,” Box 69, Addenda.

${ }^{99}$ White Marsh Register, 1818-33, 1887, Box 3, Folder 4, MPC; Fr. Neale's Register, St. Thomas's, 1827-32, Box 15, Folder 18, MPA; Baptismal and Marriage Record Book, Newtown, Box 101, Folder 9, MPA; Baptismal Records St. Joseph's and Sacred Heart, Box 15, Folder 14, MPA.

${ }^{100}$ Bishop Neale to Fr. Lucas, April 19, 1816, Box 59, Folder 7, MPA.

${ }^{101}$ Fr. John Baptist Carey to Fr. Francis Neale, March 21, 1820, Box 59, Folder 8; MPA.

102 On the importance of the 1820 Kenney visitation for the history of slaveholding in Maryland, see Curran, "'Splendid Poverty," 130-32; Curran, "Peter Kenney," 191-213; Morrissey, Peter Kenney, S.J., 139-86; Murphy, Jesuit Slaveholding, 33-34, 56-57, 117.

103 Peter Kenney, “Temporalities," Box 126, Folder 7, MPA.

104 Peter Kenney, "Temporalities," Box 126, Folder 7, MPA. 
and in the meantime insisted that its members should behave with "great zeal, piety, prudence \& charity," to "check the evils attendant in the possession of slaves." 105

After Kenney's visit, the management of the Maryland plantations continued to have problems. As a result of the management issues and lingering rivalries between American and European Jesuits, Superior General Jan Roothaan (in office 1829-53) sent Kenney on a second visit in 1830. At this visitation, he was expected to "see the accounts of all receipts and expenses." 106 He found most plantations in a better state than ten years earlier. One of the few areas of improvement was the housing of the enslaved community. ${ }^{107}$ However, they were still disorganized. It was impossible to ascertain profits or losses with complete certainty as most managers had not kept records. The visitor left a documented trail of his visits to every farm and his view of the enslaved community in many of them. In the early $1830 \mathrm{~s}$, after his visit to Bohemia, he was integral to the sale of enslaved persons at that plantation after he described them as living in sinful debauchery. Upon insisting on their sale, he grew exasperated when it seemed to take longer than he wished. ${ }^{108}$

The sale of enslaved persons was one of the few events that managers recorded regularly in their financial ledgers. But even those transactions had lapses in bookkeeping. Between 1830 and June 1838, plantation managers registered the sale of at least twenty-eight persons in the Maryland mission. ${ }^{109}$ At Bohemia, Br. Benedict Joseph Heard recorded the sales of two men, a woman, and two children. At St. Thomas's Manor, the Jesuits sold four women in installments. Fr. Francis Vespré, the procurator, recorded this transaction in the province's cashbook. Meanwhile, at St. Inigoes Fr. Joseph Carbery failed to record the sale of seventeen

\footnotetext{
${ }^{105}$ Peter Kenney, "Temporalities,” Box 126, Folder 7, MPA.

${ }^{106}$ Kenney memorial, Box 126, Folder 4, MPA; "Memoranda Left by Fr. Kenney after Visiting Conewago," Box 126, Folder 4, MPA; Jan Roothaan to Peter Kenney, July 3, 1830, Box 93 Folder 7, MPA; Jan Roothaan to Peter Kenney, October 25, 1831, Box 93, Folder 7, MPA; Curran, "Peter Kenney," 204-6.

${ }^{107}$ Curran, "Peter Kenney," 204-5.

108 "Observations Made by R.F. Visitor at the Residence of St. Fr. Xavier Bohemia, June 1831," Box 126, Folder 4, MPA. On Kenney trying to broker a large sale of slaves, see Peter Kenney to John McElroy, August 19, 1832, Box 63, Folder 18, MPA; Peter Kenney to Francis Neale, September 10, 1832, Box 63, Folder 17, MPA; Peter Kenney to John McElroy, November 23, 1832, Box 63, Folder 15, MPA. On the sale of slaves at St. Joseph's on the Eastern Shore and Arabia Petrea, see "Proceedings of the Corporation of Roman Catholic Clergymen, August 6, 1833," Georgetown College, Box 24, Folder 1, MPA; Entry 1832, "Ledgerbook: St. Joseph's," Box 31, Folder 2, MPA; Peter Kenney to Thomas Mulledy, December 11, 1831, Box 1, Folder 4c, Thomas Mulledy Papers (hereafter TMP); Peter Kenney to Thomas Mulledy, July 16, 1832, Box 1, Folder 4d; Peter Kenney to John McElroy, October 26, 1832, Box 63, Folder 17, MPA.

${ }^{109}$ For the sales before the transaction of 1838, see "Father Heard's Accounts on Bohemia," Box 30, Folder 5, MPA; Accounts, January 1832, "Bohemia Ledgerbook, 1790-1870," Box 49, Folder 3, MPA; Entries 1832, "St. Joseph's Account Book," Box 31, Folder 2, MPA; September 1835, "St. Inigoes Account Ledger, 1834-1850," Box 44, Folder 2, MPA; "Annual Reports and Expenses of the Province," Box 77, MPA: Addenda; "Entry September 19, 1835"; "St Inigoes Accounts Ledger, 1834-1850," Box 44, Folder 2, MPA; "Undated Entry: 1835," Province Financial Records: Cashbook, 1834-39, Box 68, Addenda.
} 
persons in 1835. Upon discovering that Carbery had not kept "any minute or copy of [the] transaction," Vespré berated him for his negligence. He reminded him that this was "not a sale of mere produce, but of true \& real capital." Frustrated by the lack of documentation, Vespré ordered Carbery that they could not ask the purchaser for a copy of the transaction as he had suggested since doing so would "be an acknowledgement of too much negligence on our part, about so important a contract." 110

The negligence of plantation managers, along with the elevation of the Maryland mission to province in 1833, explains why the records of the largest sale orchestrated by the Jesuits were a centralized affair. In June of 1838, the new provincial of the mission, Fr. Thomas Mulledy, signed a bill to sell 272 persons to Henry Johnson and Jesse Batey of Louisiana. ${ }^{11}$ The people sold came from four Jesuit plantations. The transactions from each plantation were not settled by individual estates. Instead, the provincial, Mulledy, handled the affair and its bookkeeping. The sale of 272 enslaved persons in 1838 is one of the largest transactions in the domestic slave trade and one of the most-documented events in the history of Jesuit slaveholding Maryland. The national attention it has received has also made it one of the most scrutinized events of the history of the Jesuit order in the United States. ${ }^{112}$

The Jesuits documented the individuals they sold with more care than their usual recordkeeping practices because of the value of this transaction. In preparation for the sale, they listed the persons they planned to sell, writing their plantation of origin, ages, and families in a widespread census. In four different bills of sale, they recorded names, ages, and destinations. ${ }^{113}$ Some of these details were required by the purchasers since the Louisiana Civil Code required names, sex, age, and

\footnotetext{
${ }^{110}$ Vespré to Fr. Carbery, January 27, 1836, Letter Book 1, p. 78, Box 77, Addenda.

111 "Articles of Agreement between Thomas F. Mulledy of One Part, and Jesse Batey and Henry Johnson of the State of Louisiana of the Other Part, June 19, 1838," Box 40, Folder 10, MPA.

112 The story gained national attention thanks to the reporting of Rachel Swarns at the New York Times. See "272 Slaves Were Sold to Save Georgetown: What Does It Owe Their Descendants?," New York Times, April 16, 2016; “"A Million Questions' from Descendants of Slaves Sold to Aid Georgetown," New York Times, May 20, 2016.

113 "Census of Slaves to Be Sold in 1838," Oversize Box 4, MPA; "Articles of Agreement between Thomas F. Mulledy of Georgetown, DC, of One Part and Jesse Batey and Henry Johnson of the State of Louisiana on the Other, June 19, 1838," Box 40, Folder 10, MPA; "Bill of Sale for 56 Slaves from Thomas Mulledy to Henry Johnson, November 10, 1838," Box 40, Folder 10, MPA; "Bill of Sale for 64 Slaves from Thomas Mulledy to Jesse Batey, November 10, 1838," Box 40, Folder 10, MPA; "Bill of Sale for 84 Slaves from Thomas Mulledy to Henry Johnson, November 29, 1838," Box 40, Folder 10, MPA; "Undated Bill of Sale for 11 Slaves from Thomas Mulledy to Henry Johnson," Box 40, Folder 10, MPA.
} 
nationality of all persons mortgaged. ${ }^{114}$ However, despite the increased level of detail, these records are still ambiguous. In some documents, the Jesuits appeared to be unsure of the names of the persons they were selling, as in the case of a female listed as "Ellen or Eleanor." 115 Some of the persons listed on their census were never sold. ${ }^{116}$ Moreover, researchers have discovered conflicting accounts of the number of persons actually sold by the Jesuits in this transaction. Although the Jesuits listed 272 as sold, Sharon Leon's study of the sale of 1838 suggests the possibility that up to 320 persons were sold in that transaction. ${ }^{117}$

Most of the documentation of the sale produced by the Jesuits appears to have been for the internal use of the province. For example, after the first group of enslaved persons left the plantations in November of 1838, they also registered the names of the persons who remained at the Jesuit estates although they had been sold to Louisiana. As provincial, Mulledy also preserved the receipts of the cost of transporting enslaved persons from the plantations to the port of Alexandria, as well as multiple letters discussing the event. ${ }^{118}$ Most of these documents were held in

${ }^{114}$ See Article 3274, Civil Code of the State of Louisiana, with annotations by Wheelock S. Upton, LL.B., and Needler R. Jennings (New Orleans: E. Johns \& Co. Stationers' Hall, 1838), 497; William Brent to T. Mulledy, Box 40, Folder 9, MPA.

115 "Bill of Sale for 64 Slaves from Thomas Mulledy to Jesse Batey, November 10, 1838," Box 40, Folder 10, MPA.

${ }^{116}$ Isaac Hawkins, the first person listed on the census of 1838, was never sold to Louisiana. Jesuit correspondence from the 1840s documents his presence at the White Marsh plantation. See Fidelis Grivel to Charles Lancaster, November 6, 1838, Box 66, Folder 3, MPA; Fidelis Grivel to Charles Lancaster, May 4, 1839, Box 66, Folder 1, MPA; Fidelis Grivel to Charles Lancaster, April 15, 1842, Box 67, Folder 7, MPA. Other persons escaped before being sold to Louisiana. They appear in Jesuit records in Maryland in the 1840s, although the documents of the sale of 1838 list them as sold. For the case of Isaac Hawkins's fourth son, see Francis Vespré to Bailliff Samuel H. Redgrave, August 14, September 4, Letter Book 1, pp. 405-6; 410; Box 77, Addenda; Francis Vespré to Bailliff Samuel H. Redgrave, September 7, November 4, 1843; Letter Book 2, pp. 3-4; 7-8; Box 77, Addenda. For the case of Louisa Mason, see "Account September 29, 1839," Day and Cashbook, 190E, Box 68, Addenda; John McElroy to Jesse Batey, February 18, 1840, Letter Book 1, pp. 147-49, Addenda.

${ }^{117}$ Historian Sharon Leon notes that "although the articles of agreement specify that 272 people are being sold, the 1838 census document lists 278 people." Her most recent data analysis lists up to 319 persons sold in 1838. See Sharon Leon, "Re-presenting the Enslaved Community Sold by the Maryland Province Jesuits in 1838," September 30, 2016; http://www.6floors.org/bracket/2016/09/30/re-presenting-the-enslaved-community-sold-by-the-maryland-province-jesuits-in1838/ (accessed August 21, 2020). For her data and research, see "1838 Census Data," JPPDataSharon Leon, Github.com; https://github.com/sharonmleon/JPPData (accessed August 21, 2020); Sharon M. Leon, "Jesuit Plantation Project"; https://jesuitplantationproject.org/s/jpp/page/welcome/ (accessed August 21, 2020).

118 "Receipt November 12, 1838," Agent's Cashbook Kept by Charles Sewall, Box 69, Addenda; "List of Slaves Remaining on the Estate, No Date," Box 40, Folder 6, MPA; "Expenses for the Transportation of Slaves from St. Inigoes," Province Financial Records Cashbook, 1834-39, Box 68, Addenda; "Receipt for Transporting 32 Slaves from Newtown," Scrap of Paper, Agent's Cashbook Kept by Charles Sewall, Box 69, Addenda; "Receipt Passage of Servants, November 12, 1838," Agent's Cashbook Kept by Charles Sewall, Box 69, Addenda; "Expenses from Transporting Servants from St. Thomas's Manor," Agent's Cashbook Kept by Charles Sewall, Box 69, Addenda; "Receipt, June 25, 1838," Agent's Cashbook Kept by Charles Sewall, Box 69, Addenda. 
the archives of the provincial and procurator, not in the ledgers of the different temporalities. ${ }^{119}$ They also preserved copies of the multiple mortgages related to the sale and kept an inventory of documents pertaining to the distinct transactions with Jesse Batey and Henry Johnson. ${ }^{120}$ The records of the sale of 1838 were integral to the Jesuits' business dealings in the aftermath of the transaction. From 1838 to 1862 , the Jesuits battled over the payment of the sale of their enslaved community, finally settling the affair in May $1862 .{ }^{121}$

However, the sale of most of the Jesuits' enslaved community did not end the priests' difficulties with documenting the persons they held in bondage. During the $1840 \mathrm{~s}$, priests continued to ignore their obligation to record expenditures, including those related to the enslaved community they still maintained in their missions. Enslaved persons rarely appear in Jesuit accounts despite the fact that at least forty-eight persons remained in bondage at nine Jesuit estates in $1840 .{ }^{122}$ In St. Inigoes' accounts, for example, there is no mention of a "slave" or a "servant"

${ }^{119}$ In 1905, Joseph Zwinge, the procurator of the Maryland province, mentioned that most of the documents related to the sale were within the records of one of the longest serving procurators of the province, Fr. Charles Lancaster. See Joseph Zwinge to Fr. Devitt, January 18, 1905, Georgetown College, Letter Book 2, Box 77, Addenda. The exception of these records was the census of slaves to be sold in 1838. Zwinge found this document within the records of the superior at Newtown. See annotation in "Census of Slaves to Be Sold in 1838," Oversize Box 4, MPA.

120 "Batey-Mulledy Mortgage, September 18, 1838," Box 40. Folder 9, MPA; “Johnson-Mulledy Mortgage, September 19, 1838," Box 40, Folder 9, MPA; “List of Documents Pertaining to Sale, to Jesse Batey 1838," Box 40, Folder 10, MPA; "List of Documents Pertaining to the Sale to Henry Johnson, 1839," Box 40, Folder 10, MPA.

${ }^{121}$ On the financial disputes between Henry Johnson and the Jesuits of Maryland, see Income: "Entry March 28, 1840," "Entry April 5, 1841," "July 7, 1841," "August 9, 1841," Expenses: "February 21, 28, 1841," “April 13, 1841," "December 31, 1841," Day and Cash Book, 1839-60, 190E, Box 68, MPA: Addenda; “Account 141: Maryland Province," “Account Edmund Forestall," Bill Book November 1840-June 16, 1846 (I.A.6.g), GUA; Brother Sylvester Clarke's Memoranda Book, Miscellaneous Legers Box 1, GUA. Agreement between Gov. Henry Johnson of the Parish of Ascension, LA, and Edmund John Forstall, acting on behalf of Rev. Mulledy, February 17, 1844, Box 40, Folder 6, MPA; Francis Vespré to Thomas Mulledy, March 25, 1844, Letter Book 2, p. 20, Box 77 Maryland Province Addenda; "Johnson and Batey Accounts," 4, Day and Cash Book, 183960, 190E, Box 68, MPA: Addenda; "Entries 1844," "Edmund Forestall Deposits 1843-1844 Georgetown," Ledger 1839-65, 191A, Box 68, Maryland Province Addenda; "Renegotiation Terms of Sale," February 17, 1844, Box 40, Folder 10, MPA. The last payment from the sale was in May 20, 1862; see Ledger 1839-65, Box 68, Addenda; Thomas Mulledy to Henry Johnson, March 31, 1844, Box 40, Folder 6, MPA.

122 The federal census returns of 1840 at White Marsh, Alexandria, Frederick, St. Thomas's Manor, Newtown, St. Inigoes, Bohemia, St. Joseph's, and White Marsh all list enslaved persons at the properties. See Matthia Sanders, 1840; Census Place: Harford, Maryland; Roll: 167; p. 106; Stephen L. Dubuisson, 1840; Census Place: Alexandria, Alexandria, District of Columbia; Roll: 35; p. 207; John McElroy, Year: 1840; Census Place: Frederick, Frederick, Maryland; Roll: 165; p. 123; Thomas Lilly, 1840; Census Place: District 2, Charles, Maryland; Roll: 163; p. 190; Ignatius Combs, Ignatius Combs, 1840; Census Place: District 3, Saint Mary's, Maryland; Roll: 170; p. 151; Joseph Carbery, 1840; Census Place: District 1, Saint Mary's, Maryland; Roll: 170; p. 132; George King, 1840; Census Place: Calvert, Maryland; Roll: 163; p. 130; C. C. Lancaster, 1840; Census Place: District 4, Talbot, Maryland; Roll: 171; p. 55. 
after 1842. At the same time, taxation records and returns from the federal census reveal eight enslaved persons at the plantation. ${ }^{123}$

After the sale of 1838, enslaved persons only appear in Jesuit records when they were involved in purchases or controversies. A man named Len appears in plantation records because his purchase by Fr. Robert Woodley was a matter of debate within the province. A woman named Nelly surfaces in multiple letters and accounts as superiors battled over her housekeeping labor and her eventual removal from Jesuit properties. ${ }^{124}$ A young man named Alexius is present in province accounts because of his purchase by Thomas Lilly in 1845 . The presence of an elderly woman named Sucky, along with a group of elderly persons at White Marsh, was recorded for over a decade because the province repeatedly sent money to that estate, particularly after there were worries that they were "being starved with hunger and cold." 125 Besides these individuals, there are very few traces of enslaved persons at the plantations. In fact, there are indications of the destruction of many records of the province in the period, as Fr. James Curley reported spending "an hour or two a day for some weeks looking over some old papers for the province in order to burn useless papers." 126

With their lapses in recordkeeping, it is unsurprising that the last enslaved persons recorded at the Jesuit plantations were not documented by the Jesuits. The power of the state and a person's status as property were the two factors that determined their documentation by external agents. In 1867, the state of Maryland prepared a census of people who were emancipated in the state in 1864 . The purpose of this census was to prepare the state for the possibility of compensating enslavers for their loss of property. At St. Mary's County, William Holly, Louisa

\footnotetext{
${ }^{123}$ Joseph Carbery, 1840; Census Place: District 1, Saint Mary's, Maryland; Roll: 170; p. 132; "St. Inigoes Tax Assessment, 1841," St. Mary's County Board of County Commissioners (Assessment Records), 1841-1917, C1528, Maryland State Archives.

${ }^{124}$ On Woodley's management of Newtown and the purchase of an enslaved man named Len, see "Newtown Sale and Rental Agreements," Box 6, Folder 5, MPC; Fr. Vespré to Fr. Woodley, April 16, 1844, Letter Book 2, p. 23, Box 77, Addenda. On the disputes over Nelly, an enslaved housekeeper, see Fr. Francis Dzierozynski to Fr. Lancaster, January 29, 1843, Box 68, Folder 12, MPA; Robert Woodley to Ignatius Brocard, September 16, 1850, Box 71, Folder 10, MPA; Robert Woodley to Ignatius Brocard, September 25, 1850, Box 71, Folder 10, MPA; Fragment: Robert Woodley, Box 15, Folder 12, MPA.

${ }^{125}$ On the purchase of Alexius from Capt. Thomas Carbery, see "September 1845," Day and Cash Book 190E, Box 68, Addenda. On the presence of enslaved persons at White Marsh, see "Copy of Consultation, February 27, 1843," Box 126, Folder 2, MPA; Entries "January 17, 1840," "February 3, 1840," "March 19, 1840," "June 22, 1840," "November 1842," "October 1843," "January 1845," "February 1847," "February 1848," "December 1849," "January 1851," "March 1851," "May 1851," "September 1851," "January 1852," "February 1852," "April 1852," "May 1852," "July 1852," "September 1852," "April 1853," "May 1853," "September 1853," "October 1853,", "February 1854," "August 1854," "October 1854," "October 1855," "February 1856," "January 1857," "April 1857," "December 1857," "March 1858," Day and Cash Book, Box 68, Addenda.

126 "Notes: Fr. James Curley," Box 1, Folder 2, James Curley, S.J. Papers, Booth Family Center for Special Collections, Georgetown University Library.
} 
Mason, and her children Daniel, Ann, Charity, Thomas, Josephine, and Robert were listed as property of the "Corporation of the Roman Catholic Church Clergymen by Rev. I. B. Meucer." 127 Accounting records only offer fragments of their lives under slavery. ${ }^{128}$

\section{Conclusion}

After the Civil War, the Jesuits made a conscious effort to forget their history of slaveholding. Their attempts to conceal their participation in the slave trade went as far as not asking for government compensation after the occupation of their properties by the Union army, since they considered that doing so would "rake up reminisces about the southern proclivities of many of ours." 129 However, at the turn of the twentieth century, Jesuit priests curious about their past tried to understand their slaveholding history. As a result, the Woodstock Letters published a series of articles related to Jesuit slaveholding in Maryland. However, while researching and writing these articles, their authors, Fr. Edward Devitt and Fr. Joseph Zwinge, were forced to confront the disjointed nature of the province's archive. ${ }^{130}$ In the absence of many records, Zwinge turned to the Jesuits' formerly enslaved community to learn about this past. Louisa Mason, one of the last women enslaved by the Jesuits,

\footnotetext{
${ }^{127}$ Agnes Kane Callum, ed., Slave Statistics of St. Mary's County Maryland, 1864, Commissioner George B. Dent, Maryland State Archives (Baltimore: Mullac Publishers, 1993), 369:102. The text is also online https://msa.maryland.gov/megafile $/ \mathrm{msa} / \mathrm{specol} / \mathrm{sc} 2900 / \mathrm{sc} 2908 / 000001$ $/ 000369 / \mathrm{html} /$ index.html (accessed September 22, 2020). The name of the Jesuit priest was John B. Meurer.

${ }^{128}$ See "St. Inigoes Accounts," Box 44, Folder 2, MPA; "St. Inigoes Ledger," Box 43, Folder 1. A woman called Louisa is named between 1854 and 1855 in an account record at St. Inigoes, but it is unclear if it is Louisa Mason or a woman rented to the Jesuits by a tenant. See "St. Inigoes: Saw Mill Ledger, 1821-1858," Box 43, Folder 1, MPA.

129 "Consultation November 1, 1872," Consultations March 2, 1870-December 5, 1878, Box 6, Folder 2, House Diaries and Consultors Books, GUA.

${ }^{130}$ For Zwinge's research on the Jesuit plantations, see Joseph Zwinge, S.J., "The Jesuit Farms in Maryland," Woodstock Letters 39, no. 3 (October 1, 1910): 374-83; Zwinge, "Jesuit Farms in Maryland," Woodstock Letters 40, no. 1 (February 1911): 65-77; Zwinge, "The Jesuit Farms in Maryland," Woodstock Letters 40, no. 2 (June 1911): 180-99; Zwinge, "The Jesuit Farms in Maryland," Woodstock Letters 41, no. 1 (February 1912): 53-77; Zwinge, "The Jesuit Farms in Maryland, Facts and Anecdotes," Woodstock Letters 41, no. 2 (June 1, 1912): 195, 203-4; Zwinge, "The Jesuit Farms in Maryland, Facts and Anecdotes," Woodstock Letters 41, no. 3 (October 1912): 275-91; Zwinge, "The Jesuit Farms in Maryland: Tenants," Woodstock Letters 42, no. 1 (February 1, 1913): 1-13; Zwinge, "The Jesuit Farms in Maryland," Woodstock Letters 42, no. 23 (October 1, 1913): 336-52; Zwinge, "The Jesuit Farms in Maryland," Woodstock Letters 43, no. 2 (June 1, 1914): 194201. For some of Devitt's publications on the province's history, see Edward I. Devitt, S.J., "The Suppression and Restoration of the Society in Maryland," Woodstock Letters 33, no. 3 (December 1, 1904): 371-82; Devitt, "The Suppression and Restoration of the Society in Maryland," Woodstock Letters 34, no. 1 (April 1, 1905): 113-31; Devitt, "The Suppression and Restoration of the Society in Maryland," Woodstock Letters 34, no. 2 (September 1905): 203-36;
} 
was integral to Zwinge's published research. She appears in many of his writings as "Aunt Louisa." ${ }^{131}$ Her memory filled the gaps left by inconsistent recordkeeping.

During the time of Devitt's and Zwinge's writings, the Maryland province archives were not only plagued by the legacy of erratic bookkeepers but by rampant disorganization. After Devitt had been "dusting the archives," searching for materials related to their upcoming Jubilee, he wrote to Zwinge to express his interest in looking up documents related to the sale of part of their enslaved community in 1838. In his reply, Zwinge informed him that

besides the letters in the "Letter Books" which you have probably examined, I found a great many others amongst Mr. Lancaster's papers. These negroes have caused so much trouble that it would pay to gather them all together and stuff them into a pouch by themselves there to remain in quiet until some old antiquarian hustled them out again. Fr. Prov. was surprised to hear the archives were not fully enough catalogued. Will you please inquire how much a catalogue outfit would cost, box, cards, pouches etc and where to get these things. Fr. Shandelle could probably tell. ${ }^{132}$

The Maryland mission founded their first archive during the time of the suppression, under the auspices of the Corporation of Roman Catholic Clergymen in a fireproof room at Georgetown College. ${ }^{133}$ During that time, the focus on their property made them preserve with varied degrees of success their property titles. The records concerning their slaveholding past always focused on their view of the persons they held in bondage as property. Once the financial interest of preserving these records disappeared, so did their interest in preserving and organizing these documents. By 1905, these records appeared to have held little importance to the mission. They were uncatalogued and scattered.

The recordkeeping practices of the Maryland Jesuits are part of the history of slaveholding in the Maryland province. An analysis of Jesuit recordkeeping reveals that the Jesuits viewed enslaved persons primarily as a source of wealth. They

\footnotetext{
131 "Nota Bene: Joseph Zwinge," Addenda Annual Reports 196B, pp. 148-49; Box 77, MPA: Addenda, "Annotations by Joseph Zwinge on the History of St. Inigoes Graveyard," Box 15, Folder 3, MPA; "Zwinge's Annotations on St. Inigoes Account Book, 1816-1832," Box 44, Folder 1, MPA; Joseph Zwinge, "The Jesuit Farms in Maryland, Facts and Anecdotes," Woodstock Letters 41, no. 2 (June 1, 1912): 195, 203-4; Zwinge, "The Jesuit Farms in Maryland, Facts and Anecdotes," Woodstock Letters 41, no. 3 (October 1912): 275-91. For information on Mason's life, see Louisa Mason's obituary, St. Mary's Beacon, July 22, 1909.

132 Joseph Zwinge to Edward Devitt, January 18, 1905, Georgetown College, Letter Book 2, Box 77, Addenda.

133 "Proceedings of the Corporation of Roman Catholic Clergymen," February 15, 1816, Georgetown College, Box 24, Folder 1, MPA.
} 
recognized their humanity by baptizing and marrying them, but even sacramental records are permeated by their view of individuals as property. Baptisms name enslavers, they are used to account property, and in the case of the Jesuits, enslaved community sacraments were often recorded among documents concerning lands, cattle, and crops. While slaveholding Jesuits attempted to see enslaved persons as part of the body of Christ, their records reveal they often saw them only as a part of the sum of their wealth.

Financial motives permeated all aspects of Jesuit recordkeeping of their enslaved community. The current organization of the province archive reflects the primacy of property over any other documentation. The periods of increased detail in documentation related to the Maryland Jesuits' enslaved community reveal that they only recorded details of the lives of enslaved persons if their property was at stake, or if an external pressure, such as the state, internal developments of the American church, or Rome forced them to do so. These disjointed practices hold meanings, intentions, and the purposes of the Maryland Jesuits. The order, the descendant community looking for their ancestors, and researchers must now grapple with the consequences of the recording practices of the Jesuits as they try to make sense of the realities of Jesuit slaveholding and the documentary traces that the Jesuits left behind of those that they enslaved. 